\title{
Safety and Efficacy of SLT vs ALT - Short and Longer Term Perspectives
}

\author{
Fisseha Admassu Ayele* \\ Department of Ophthalmology, University of Gondar, Ethiopia
}

Submission: January 10, 2018; Published: February 09, 2018

*Corresponding author: Fisseha Admassu Ayele, Consultant ophthalmologist (Cataract, glaucoma) Assistant professor of Ophthalmology, University of Gondar, Gondar, Ethiopia, Tel: +251911197786; Email: drfisseha@yahoo.com

\section{Introduction}

Laser treatment of the anterior chamber angle seems to have been first described in 1961 by Zweng and Flocks using a xenonarc light source in cats, dogs, and monkeys [1]. Laser treatment of the human trabecular mesh work by puncturing Schlemm's canal was performed initially by Krasnov [2], but the lower intraocular pressure (IOP) he described was short-lived [2]. Argon laser trabeculotomy in humans and monkeys was reported by Worthen \& Wickham [3]. Subsequently, Ticho \& Zuberman noted that Argon laser treatment of the angle wassuccessful in lowering IOP despite lack of permanent trabecular openings [4].

Contemporary use of Argon laser trabeculoplasty (ALT) is basedon a report demonstrating safety and efficacy in a group of open-angleglaucoma patients in 1979 by Wise \& Witter [5]. In 1998, Latina and colleagues utilized a frequency-doubled neodymium:yttrium - aluminum - garnet (Nd:YAG) nonthermal laser to lower IOP successfully in patients with openangle glaucoma [6]. This laser works by utilizing selective photothermolyis, selectively targeting melanin and melanin laden cells with minimal collateral damage to adjacent structures, and hence is referred to as selective laser trabeculoplasty (SLT) $[7,8]$.

Although other lasers have been utilized for laser trabeculoplasty, ALT and SLT appear to be the most common methods employed.Very few publications have compared these two laser modalities, and this review examines evidence for short and longer term efficacy and safety based on these studies [9-20]. One of these studies was pivotal in obtaining FDA approval for the SLT in the USA [21].

\section{Methods}

A search for studies comparing SLT to ALT in open angle glaucoma were conducted using PubMed and Google. Key search terms were selective laser trabeculoplasty and argon laser trabeculoplasty and the search was performed on February 14, 2017.

\section{Efficacy}

12 studies were found, and of these 2 involved a retrospective comparison, and 10 prospective. 3 of the studies were prospective randomized in design. Other aspects of study characteristics including results are summarized in Table 1. Nearly all treatments involved applying laser to 180 degrees of the meshwork in eyesthat had received previous medical therapy. The vast majority of studies had a preponderance of primary open angle glaucoma (POAG) patients compared to other subtypes of glaucoma. All studies conclude that there were no significant differences in IOP lowering between SLT and ALT groups i.e. SLT is equivalent to ALT in short and longer term efficacy.

Table 1: Efficacy of SLT vs ALT: summary of study design, findings, and limitations.'

\begin{tabular}{|c|c|c|c|c|c|}
\hline Study & $\begin{array}{c}\text { Design/Glaucoma } \\
\text { type }\end{array}$ & $\begin{array}{c}\text { Sample size } \\
\text { (eyes) }\end{array}$ & $\begin{array}{c}\text { Duration } \\
\text { (longest) }\end{array}$ & Findings & Limitations \\
\hline Liu et al. [9] & $\begin{array}{c}\text { Prospective } \\
\text { randomized control } \\
\text { trial; mostly POAG }\end{array}$ & $\begin{array}{c}42(20 \mathrm{SLT} \\
\text { and 22 ALT) }\end{array}$ & 2 years & $\begin{array}{c}\text { Significant IOP decrease of 11.1\% } \\
\text { after ALT (P=0.01) and 7.7\% after } \\
\text { SLT (P=0.01) with no statistical } \\
\text { difference between the lasers } \\
\text { (P>0.05) }\end{array}$ & $\begin{array}{c}\text { Small sample size, both eyes } \\
\text { treated although only first } \\
\text { analyzed. Low mean baseline } \\
\text { IOP for both groups prior to } \\
\text { laser }\end{array}$ \\
\hline Si et al. [10] & $\begin{array}{c}\text { Prospective } \\
\text { randomized. Only } \\
\text { exfoliation patients } \\
\text { enrolled. }\end{array}$ & $\begin{array}{c}76(45 \text { SLT, } 31 \\
\text { ALT) }\end{array}$ & 1 year & $\begin{array}{c}-6.2 \text { mmHg and }-8.6 \mathrm{mmHg} \\
\text { decrease with SLT and ALT, } \\
\text { respectively. No significant } \\
\text { difference. }\end{array}$ & $\begin{array}{c}\text { Pretreatment IOP higher } \\
\text { for ALT vs SLT (25.2 vs. 23.1 } \\
\text { mmHg; p=0.03). 36\% loss to } \\
\text { follow-up at 1 year. }\end{array}$ \\
\hline
\end{tabular}




\section{JOJ Ophthalmology}

\begin{tabular}{|c|c|c|c|c|c|}
\hline Bovell et al. [11] & $\begin{array}{c}\text { Prospective } \\
\text { randomized control } \\
\text { trial; mostly POAG } \\
\text { with some XFG and } \\
\text { PG }\end{array}$ & $\begin{array}{l}176 \text { (89 SLT } \\
\text { and } 87 \text { ALT) }\end{array}$ & 5 years & $\begin{array}{l}\text { Baseline similar in both groups. } \\
\text { IOP lowering at } 5 \text { yrs SLT }-7.4 \\
\pm 7.3 \mathrm{mmHg} \text { vs ALT }-6.7 \pm 6.6 \\
\text { mmHg; } \mathrm{p}=0.298 \text {. Large but } \\
\text { similar number of interventions } \\
\text { in both groups over study period }\end{array}$ & $\begin{array}{l}\text { Trial not designed for } 5 \text { year } \\
\text { follow-up. Moderate loss } \\
\text { to follow-up (64 SLT eyes } \\
\text { remaining and } 56 \text { ALT at } \\
\text { 5yrs). }\end{array}$ \\
\hline $\begin{array}{l}\text { Almeida et al. } \\
\text { [12] }\end{array}$ & $\begin{array}{c}\text { Prospective, } \\
\text { non-randomized } \\
\text { interventional case } \\
\text { series; mostly POAG }\end{array}$ & $\begin{array}{l}45 \text { (25 SLT } \\
\text { and } 20 \mathrm{ALT})\end{array}$ & 6 months & $\begin{array}{l}\text { IOP reduction with SLT } 5.1 \pm 2.5 \\
\text { mmHg and ALT } 4.4 \pm 2.8 \mathrm{mmHg} \\
\qquad \mathrm{p}=0.38\end{array}$ & $\begin{array}{l}\text { Small sample size, non- } \\
\text { randomized, short follow-up }\end{array}$ \\
\hline Russo et al. [13] & $\begin{array}{l}\text { Prospective } \\
\text { randomized control } \\
\text { trial; mostly POAG }\end{array}$ & $\begin{array}{l}120 \text { (61 SLT, } \\
59 \mathrm{ALT})\end{array}$ & 12 months & $\begin{array}{c}\text { IOP lowering with SLT } 6.01 \\
\text { mmHg and ALT } 6.12 \mathrm{mmHg} \\
\mathrm{p}=0.794 . \text { No significant difference }\end{array}$ & Small sample size \\
\hline Best et al. [14] & $\begin{array}{l}\text { Prospective non- } \\
\text { randomized }\end{array}$ & $\begin{array}{l}165 \text { (124 SLT } \\
\text { and } 41 \text { ALT) }\end{array}$ & 12 months & $\begin{array}{c}\text { Mean pressure reductions } 1.8 \\
\text { mmHg }(8.5 \%) \text { after SLT, and } \\
2.1 \mathrm{mmHg}(9.4 \%) \text { after ALT. No } \\
\text { significant difference }\end{array}$ & \\
\hline Damji et al. [15] & $\begin{array}{c}\text { Prospective } \\
\text { randomized control } \\
\text { trial }\end{array}$ & $\begin{array}{l}176 \text { (89 SLT } \\
\text { and } 87 \text { ALT) }\end{array}$ & 1 year & $\begin{array}{l}\text { Decrease in IOP at } 1 \text { year for SLT } \\
5.86 \mathrm{mmHg} \text { and ALT } 6.04 \mathrm{mmHg} \\
\qquad \mathrm{p}=0.846\end{array}$ & $\begin{array}{l}\text { IOP taken by one individual } \\
\text { not masked to treatment. } \\
\text { Some treated patients had } \\
\text { prior ALT. }\end{array}$ \\
\hline $\begin{array}{l}\text { Van de veire } S \text { et } \\
\text { al. [16] }\end{array}$ & $\begin{array}{c}\text { Retrospective } \\
\text { interventional case } \\
\text { series; mostly POAG }\end{array}$ & $\begin{array}{l}56(38 \text { SLT } \\
\text { and } 18 \text { ALT) }\end{array}$ & 3-5 weeks & $\begin{array}{c}\text { IOP-reduction was } 22.4 \% \text { after } \\
\text { ALT and } 15.5 \% \text { after SLT; } \mathrm{p}= \\
0.141\end{array}$ & $\begin{array}{l}\text { Small sample size, } \\
\text { retrospective design with } \\
\text { selection bias as patients } \\
\text { preferentially received ALT } \\
\text { or SLT depending on TM } \\
\text { pigmentation. } 4 \text { eyes were } \\
\text { excluded from analysis } \\
\text { because of post treatment } \\
\text { IOP rise. }\end{array}$ \\
\hline Juzych et al. [17] & $\begin{array}{l}\text { Retrospective chart } \\
\text { review; only POAG } \\
\text { patients enrolled }\end{array}$ & $\begin{array}{l}195 \text { (41 SLT } \\
\text { and } 154 \text { ALT) }\end{array}$ & $\begin{array}{l}\text { Mean follow- } \\
\text { up } 37.4 \pm 14.7 \\
\text { months (SLT) } \\
\text { and } 33.6 \pm 17.0 \\
\text { months (ALT) }\end{array}$ & $\begin{array}{l}\text { No statistically significant } \\
\text { difference in IOP reduction } \\
\text { between two groups using two } \\
\text { different success criteria }\end{array}$ & $\begin{array}{c}\text { Retrospective design with } \\
\text { selection bias as patients } \\
\text { underwent SLT or ALT based } \\
\text { on availability }\end{array}$ \\
\hline $\begin{array}{l}\text { Martinez de la } \\
\text { casa et al. [18] }\end{array}$ & $\begin{array}{l}\text { Prospective non- } \\
\text { randomized study; } \\
\text { only POAG patients } \\
\text { enrolled }\end{array}$ & $\begin{array}{l}40(20 \text { SLT } \\
\text { and } 20 \mathrm{ALT})\end{array}$ & 6 months & $\begin{array}{l}\text { Reduction in IOP for SLT } 22.2 \% \\
\text { (range } 0-36.3 \% \text { ) and ALT } 19.5 \% \\
\text { (range } 0-30.2 \% \text { ). P=0.741 }\end{array}$ & $\begin{array}{l}\text { Small sample size, unclear } \\
\text { methodology of how patients } \\
\text { assigned to SLT or ALT group }\end{array}$ \\
\hline Popiela et al. [19] & $\begin{array}{l}\text { Prospective } \\
\text { randomized; mostly } \\
\text { POAG }\end{array}$ & $\begin{array}{l}27 \text { patients } \\
\text { with one eye } \\
\text { receiving SLT } \\
\text { and the other } \\
\quad \text { ALT }\end{array}$ & 3 months & $\begin{array}{l}\text { Mean IOP drop - } 2.85+/-4.62 \\
\text { mm Hg after SLT and }-2.63+/- \\
3.60 \mathrm{~mm} \text { Hg after ALT; } \mathrm{p}=0.84 \text { ). } \\
\text { No significant difference in IOP } \\
\text { reduction between two groups }\end{array}$ & $\begin{array}{c}\text { Pretreatment IOP higher } \\
\text { in ALT eyes vs. SLT ( } 21.3 \text { vs } \\
\text { 20.3; p=0.04). No control for } \\
\text { crossover effect. }\end{array}$ \\
\hline Holló [20] & $\begin{array}{l}\text { Prospective non- } \\
\text { randomized study; } \\
\text { mostly POAG }\end{array}$ & $\begin{array}{l}14 \text { patients } \\
\text { with one eye } \\
\text { receiving SLT } \\
\text { and the other } \\
\text { ALT }\end{array}$ & 1-18 months & $\begin{array}{l}\text { IOP lowering varied between } \\
0-3 m m \text { Hg in each eye. No } \\
\text { significant difference in IOP } \\
\text { lowering between eyes detected. }\end{array}$ & Small sample size \\
\hline
\end{tabular}

XFG: Exfoliation Glaucoma; XFS: Exfoliation Syndrome; PG: Pigmentary Glaucoma; POAG Primary Open Angle Glaucoma

Notes: For ALT all studies utilized a 50 micron spot size and $0.1 \mathrm{msec}$ duration. For SLT all studies utilized a 3nsec pulse and 400 micron spot.

It is worth noting that the effect of SLT and ALT diminishes with time at about the same rate. This is illustrated in the study by Bovell et al. [11] which indicates that time to $50 \%$ failure in each group was approximately 2 years [11] (Figure 1). The definition of success employed in this study was $20 \%$ IOP lowering with no additional medical, laser, or surgical interventions. The survival rate of persons after having received SLT was $44 \%$ at 3 years; at 4 years it was $38 \%$; and at 5 years it was $25 \%$. For patients who received ALT, survival at 3 yearswas $37 \%$; at 4 years, 30\%; and at 5 years, $27 \%$ It is worth noting that patients enrolled in the study were on maximal tolerated medical therapy, and required a large number of subsequent interventions (laser trabeculoplasty, incisional surgery, and cyclophoto coagulation) in both groups, over the 5-year follow-up period (49/89 SLT and 33/87 ALT eyes). 


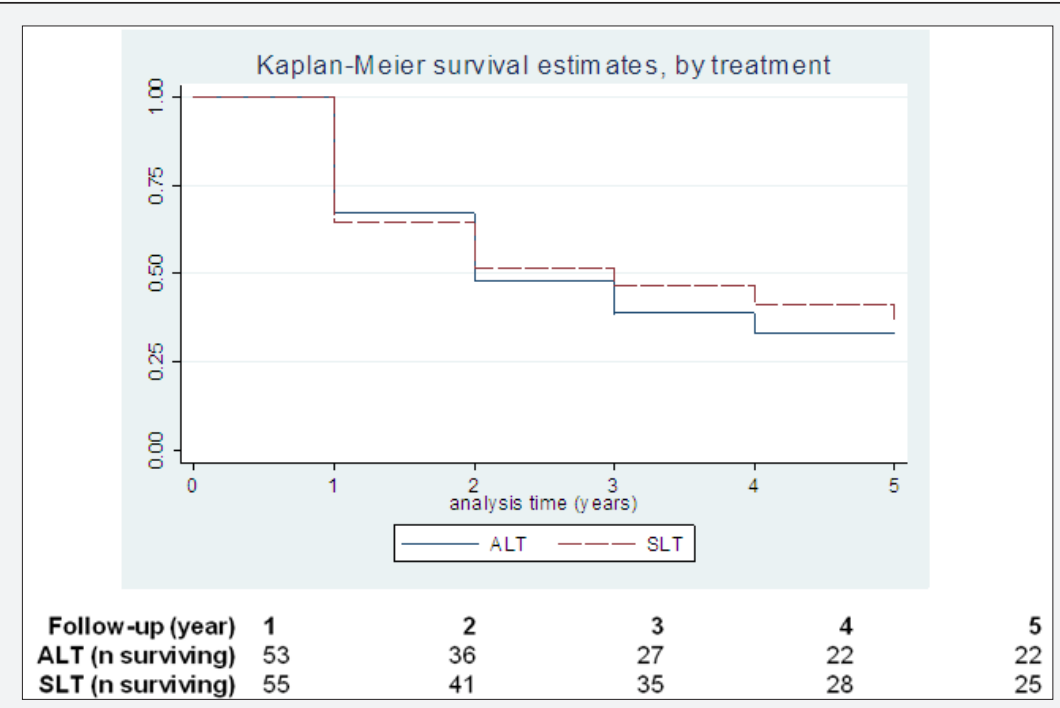

Figure 1: Survival analysis of all patients in the study by Bovell et al. [11]. Success is defined as at least $20 \%$ lowering of intraocular pressure with no additional medical, laser, or surgical interventions (reproduced with permission from Elsevier).

\section{Safety}

The most common complication reported in clinical studies of laser trabeculoplasty is an increase in IOP with highest spikes occurring within the first hour - although they may be delayed [22]. In a prospective randomized control trial, the reported incidence of increase in IOP greater than $6 \mathrm{mmHg}$ from baseline 1 hour after SLT and ALT in patients who were prophylactically treated for a pressure spike with an alpha adrenergic agonist was 3.4\% in ALT-treated eyes and 4.5\% in SLT-treated eyes [15]. These spikes typically resolve quickly with the addition of IOP lowering therapy [23]. If no prophylactic agent was used, the incidence of spikes in one SLT study was $25 \%$ [24], and in one ALT study $34 \%$ of eyes [25].

Heavy pigmentation of the trabecular meshwork has been strongly associated with IOP rises in both types of laser trabeculoplasties. There is a report of a case series by Harasymowycz et al. [22] with persistent elevation of IOP following SLT in eyes with heavily pigmented trabecular meshwork that required trabeculectomy [22]. The risk of such complications may be reduced by decreasing the power or treating less trabecular meshwork [15].

Other complications of laser trabeculoplasty that appear to beseen much less with SLT than ALT include pain during treatment, blurry vision and conjunctival injection. The anterior chamber flare was significantly lower in the SLT group (13.3 SD 6.3 photons/ms) than in the ALT group (20.7 SD 7.4 photons/ $\mathrm{ms}), \mathrm{P}=0.003$ in one study an hour after treatment [18].

There have been reports of some cases that developed corneal edema from 24 hours up to one week after the surgery following SLT. It is not yet understood what may predispose a patient to corneal changes as a result of this procedure, although HSV stromal keratitis reactivation as a result of inflammatory cascade following laser treatment was attributed in one case. Routine use of topical anti-inflammatory drops may avoid this complication [26,27]. The Glaucoma Laser Trial reported a 46\% rate of greater than or equal to 1 degree of peripheral anterior synechiae formation (PAS) after ALT. PAS are extremely rare following SLT treatment [25].

There are also rare complications of SLT reported including transient and uneventful hyphemas [28,29] and a case of severe iritis with chorodal effusion [30]. Unlike ALT, SLT does not destroy the outflow apparatus of the eye that gives the latter theoretical advantages that may include improvedresponse to certain glaucoma medications that rely on improving trabecular outflow, potential for repeat treatment, and preservation of the Schlemm's canal for possible future angle surgery.

\section{Future Directions for Clinical Research}

The use of lasers in glaucoma continues to evolve, with a trend towards primary and earlier intervention. Studies suggest a role for SLT as initial therapy for open-angle glaucoma and ocular hypertension and have demonstrated efficacy equal to medical therapy with prostaglandin analogue in one year [3133]. The advantages of initial laser therapy includes its safety as compared to long term use of medical therapy, compliance to treatment is not an issue and cuts costs related to medical therapy [34]. However, an important risk to mitigate is that patients may get lost to follow-up (some may feel their glaucoma is 'cured') and then return years later with uncontrolled glaucoma. Hence, although more work needs to be done comparing SLT as primary therapy to other modalities of treatment,emphasis should also be given to ensure patients and care partners are well educated about their disease and the importance of regular followup to monitor IOP, optic nerve and retinal nerve fiber layer structure, and visual field function. 
In the last decade and a half, SLT has proven to be equally effective as ALT in lowering IOP in primary open angle glaucoma and exfoliation glaucoma; however, future studies need to focus on 180 vs. 360 degree treatment, repeatability (when entire 360 degrees has been treated and additional treatment is being done) and its role, in comparison to ALT and other laser trabeculoplasty methods, in other glaucomas such as pigmentary glaucoma.

\section{References}

1. Zweng HC, Flocks M (1961) Experimental photocoagulation of the anterior chamber angle: a preliminary report. Am J Ophthalmol 52: 163-165.

2. Krasnov MM (1972) Laser puncture of the anterior chamber angle in glaucoma (a preliminary report). Vestn Oftalmol 3: 27-31.

3. Worthen DM, Wickham MG (1974) Argon laser trabeculotomy. Trans Am Acad Ophthalmol Otolaryngol 78(2): OP371-OP375.

4. Ticho U, Zauberman H (1974) Argon laser application to the angle structures in the glaucomas. Arch Ophthalmol 13: 455.

5. Wise JB, Witter SL (1979) Argon laser therapy for open angle glaucoma. Arch Ophthalmol 97(2): 319-322.

6. Latina MA, Sibayan SA, Shin DH, Noecker RJ, Marcellino G (1998) Q-switched 532-nm Nd:YAG laser trabeculoplasty (selective laser trabeculoplasty). Ophthalmology 105(11): 2082-2090.

7. Anderson RR, Parrish JA (1983) Selective photothermolysis: precise microsurgery by selective absorption of pulsed radiation. Science 220(4596): 524-527

8. Kramer TR, Noecker RJ (2001) Comparison of the morphologic changes after selective laser trabeculoplasty and argon laser trabeculoplasty in human eye bank eyes. Ophthalmology 108(4): 773-779.

9. Liu Y, Birt CM (2012) Argon Versus Selective Laser Trabeculoplasty in Younger Patients: 2-year Results. J Glaucoma 21(2): 112-115.

10. Si FF, Kent S, Hutnik CM, Birt CM, Damji K, Harasymowycz P, Hodge WG, Pan YI, Crichton A. A Prospective Randomized Clinical Trial of Selective Laser Trabeculoplasty versus Argon Laser Trabeculoplasty in Open Angle Glaucoma and Ocular Hypertension Secondary to Pseudoexfoliation. Abstract presented at: Association for Research in Vision \& Ophthalmology Annual Meeting; May 6-10, 2012; Fort Lauderdale, FL; ARVO E-abstract 6351.

11. Bovell AM, Damji KF, Hodge WG, Rock WJ, Buhrmann RR, et al. (2011) Long term effects on the lowering of intraocular pressure: selective laser or argon laser trabeculoplasty? Can J Ophthalmol 46(5): 408-413.

12. Almeida ED Jr, Pinto LM, Fernandes RA, Prata TS (2011) Pattern of intraocular pressure reduction following laser trabeculoplasty in open-angle glaucoma patients: comparison between selective and nonselective treatment. Clin Ophthalmol 5: 933-936.

13. Russo V, Barone A, Cosma A, Stella A, DelleNoci N (2009) Selective laser trabeculoplasty versus argon laser trabeculoplasty in patients with uncontrolled open-angle glaucoma. Eur J Ophthalmol 19(3): 429-434.

14. Best UP, Domack H, Schmidt V (2007) Pressure reduction after selective laser trabeculoplasty with two different laser systems and after argon laser trabeculoplasty--a controlled prospective clinical trial on 284 eyes. Klin Monbl Augenheilkd 224(3):173-179.

15. Damji KF, Bovell AM, Hodge WG, Rock W, Shah K, et al. (2006) Selective laser trabeculoplasty versus argon laser trabeculoplasty: results from a 1-year randomised clinical trial. Br J Ophthalmol 90(12): 1490-1494.

16. Van de Veire S, Zeyen T, Stalmans I (2006) Argon versus selective laser trabeculoplasty. Bull Soc Belge Ophtalmol (299): 5-10.
17. Juzych MS, Chopra V, Banitt MR, Hughes BA, Kim C, et al. (2004) Comparison of long-term outcomes of selective laser trabeculoplasty versus argon laser trabeculoplasty in open-angle glaucoma. Ophthalmology 111(10): 1853-1859.

18. Martinez-de-la-Casa JM, Garcia-Feijoo J, Castillo A, Matilla M, Macias JM, et al. (2004) Selective vs argon laser trabeculoplasty: hypotensive efficacy, anterior chamber inflammation, and postoperative pain. Eye (Lond) 18(5): 498-502.

19. Popiela G, Muzyka M, Szelepin L, Cwirko M, Nizankowska MH (2000) Use of YAG-Selecta laser and argon laser in the treatment of open angle glaucoma. Klin Oczna 102(2): 129-133.

20. Holló G (1996) Argon and low energy, pulsed Nd:YAG laser trabeculoplasty. A prospective, comparative clinical and morphological study .Acta Ophthalmol Scand 74(2): 126-131.

21. Damji KF, Shah KC, Rock WJ, Bains HS, Hodge WG (1999) Selective laser trabeculoplasty $\mathrm{v}$ argon laser trabeculoplasty: a prospective randomised clinical trial. Br J Ophthalmol 83(6): 718-722.

22. Harasymowycz PJ, Papamatheakis DG, Latina M, De Leon M, Lesk MR, et al. (2005) Selective Laser Trabeculoplasty complicated by IOP elevation in eyes with heavily pigmented trabecular meshworks. Am J Ophthalmol 139: 1110-1113.

23. Barkana Y, Belkin M (2007) Selective Laser Trabeculoplasty. Surv Ophthalmol 52(6): 634-654.

24. Latina MA, Sibayan SA, Shin DH, Noecker RJ, Marcellino G (1998) Q-switched 532-nm Nd:YAG laser trabeculoplasty (selective laser trabeculoplasty): a multicenter, pilot, clinical study. Ophthalmology 105(11): 2082-2088.

25. (1995) Glaucoma Laser Trial Research Group: The Glaucoma Laser Trial: 1. Acute effects of argon laser trabeculoplasty on intraocular pressure. Arch Ophthalmol 107(8): 1135-1142.

26. Moubayed SP, Hamid M, Choremis J, Li G (2009) An unusual finding of corneal edema complicating selective laser trabeculoplasty. Can J Ophthalmol 44(3): 337-338.

27. Regina M, Bunya VY, Orlin SE, Ansari H (2011) Corneal edema and haze after selective laser trabeculoplasty. J Glaucoma 20(5): 327-329.

28. Rhee DJ, Krad O, Pasquale LR (2009) Hyphema following selective laser trabeculoplasty. Oph Surg Lasers Imaging 40(5): 493-494.

29. Shihadeh WA, Ritch R, Liebmann JM (2006) Hyphema occurring during selective laser trabeculoplasty. Ophthalmic Surg Lasers Imaging 37(5): 432-433.

30. Kim DY, Singh A (2008) Severe iritis and choroidal effusion following selective laser trabeculoplasty. Ophthalmic Surg Lasers Imaging 39(5): 409-411.

31. M Nagar, A Ogunyomade, D P S O'Brart, F Howes, J Marshall (2005) A randomised, prospective study comparing selective laser trabeculoplasty with latanoprost for the control of intraocular pressure in ocular hypertension and open angle glaucoma. $\mathrm{Br} \mathrm{J}$ Ophthalmol 89(11): 1413-1417.

32. McIlraith I, Strasfeld M, Colev G, Hutnik CM (2006) Selective laser trabeculoplasty as initial and adjunctive treatment for open-angle glaucoma. J Glaucoma 15(2): 124-130.

33. Katz LJ, Steinmann WC, Kabir A, Molineaux J, Wizov SS, et al. (2011) Selective Laser Trabeculoplasty Versus Medical Therapy as Initial Treatment of Glaucoma: A Prospective, Randomized Trial. J Glaucoma 21(7): 460-468.

34. Cantor LB, Katz LJ, Cheng JW, Chen E, Tong KB, Peabody JW. Economic evaluation of medication, laser trabeculoplasty and filtering surgeries in treating patients with glaucoma in the US. Curr Med Res Opin 24(10): 2905-2918. 


Your next submission with Juniper Publishers
will reach you the below assets
- Quality Editorial service
- Swift Peer Review
- Reprints availability
- E-prints Service
- Manuscript Podcast for convenient understanding
- Global attainment for your research
- Manuscript accessibility in different formats
( Pdf, E-pub, Full Text, Audio)
- Unceasing customer service
Track the below URL for one-step submission
https://juniperpublishers.com/online-submission.php

